\title{
Emigracja „drugiego pokolenia”: refleksje i pytania na marginesie biografii Piotra Wandycza i Leopolda Łabędzia
}

Zarys treści: Piotr Wandycz jest jednym z najbardziej uznanych historyków polskiego pochodzenia, który zrobił karierę akademicką na Zachodzie po II wojnie, osiągając profesurę na Yale University. Leopold Łabędź, urodzony trzy lata wcześniej (w 1920), jest także przykładem błyskotliwej kariery wojennego wychodźcy z Polski - w tym wypadku w roli jednego z najbardziej uznanych w świecie sowietologów, współzałożyciela i redaktora kwartalnika „Survey”. Równoległe życiorysy tych dwóch wybitnych przedstawicieli wojennego pokolenia dwudziestolatków, którzy pozostali na Zachodzie, są tutaj kanwą do refleksji nad przemianami pojęcia i znaczenia emigracji polskiej. Punktem wyjścia jest pogląd znanego publicysty, Juliusza Mieroszewskiego, wyrażony w 1954 roku, zakładający, że nowe pokolenie polskich emigrantów będzie „wtapiało się” w życie kulturalne i polityczne krajów swojego osiedlenia i że przez to właśnie osiągnąć zdoła wpływ na świadomość polityczną elit Zachodu. Porównane między sobą przykłady decyzji życiowych i osiągnięć Piotra Wandycza i Leopolda Łabędzia są dobrą okazją do weryfikacji tej tezy.

Outline of content: Peter Wandycz is one of the most renowned historians of Polish origin to achieve academic success in the West after WWII, reaching the position of professor at Yale University. Leopold Łabędź, born three years earlier (in 1920), is another example of a brilliant career of Polish post-war emigrant, namely one of the most renowned sovietologists, as well as co-founder and editor of the quarterly "Survey". The parallel biographies of these two outstanding representatives of the generation, which experienced WWII in their twenties and decided to stay in the West, served here as a basis for reflection on the changes of the concept and importance of Polish emigration. The starting point of the consideration is the opinion expressed in 1954 by a well-known journalist, Juliusz Mieroszewski, who stated that the new generation of Polish immigrants would be melting into the cultural and political life of their countries of settlement, thus allowing them to impact on the political consciousness of the Western elites. The comparison of examples of life decisions and achievements of Peter Wandycz and Leopold Łabędź constitutes a good opportunity for the verification of this assertion.

Slowa kluczowe: Piotr Wandycz, Leopold Łabędź, polska emigracja wojenna, historia historiografii, sowietologia 
Keywords: Piotr Wandycz, Leo Labedz, polish emigration after WWII, sovietology

Polskie wychodźstwo w Londynie wytworzyło w pierwszych latach po wojnie pewien wzorzec emigracji oparty na instytucjach, rządzie, czasopismach, postawie, etosie. Generał Władysław Anders, Tymon Terlecki, prezydent Edward Raczyński, „Wiadomości”, Ognisko, Biblioteka Polska, POSK ... - oto najpiękniejsze symbole współformujące ów wzorzec.

Emigracja to jednak także zmiany, stany pośrednie, formy przejściowe, pogranicza tożsamości i ról społecznych. Być emigrantem, wiernym etosowi - i być „kimś” w kraju osiedlenia, robić w nim karierę, która nie przestaje być służbą sprawie. Ale jakiej sprawie? Do jakich granic w poszukiwaniu nowych ról wolno dojść, jakich przekroczyć nie wolno? Te pytania powstawały coraz natarczywiej, kiedy mijały lata, a perspektywa powrotu do kraju z rozwiniętymi sztandarami oddalała się w nieokreśloną przyszłość.

Zaraz po wojnie koreańskiej, zamykającej etap nadziei na rychłe, zwycięskie zakończenie politycznej misji wychodźstwa ${ }^{1}$, takie właśnie pytania - o pojmowanie sensu emigracji i nieuchronne przeobrażenia owego sensu - postawił w Londynie Juliusz Mieroszewski: „Realne perspektywy, jakie są przed nami, można ująć w dwa punkty: A. Pierwsze pokolenie emigracyjne nie wróci do Kraju i wymrze na obczyźnie. B. Młodzież tu wychowana i pokolenie urodzone za granicą w $90 \%$ pozostanie na obczyźnie nawet wówczas - jeżeli za lat 10 czy 20 otworzyłyby się możliwości powrotu do Kraju. Ponieważ powyższe perspektywy wydają się najbardziej prawdopodobne, a tym samym najbardziej realne, powinniśmy przystąpić do powolnej, systematycznej ewolucji instytucji emigracji politycznej, która zgodnie ze swą istotą jest zjawiskiem czasowym i przejściowym. Równocześnie należy zacząć organizować instytucję 'narodu w diasporze', która w przeciwieństwie do emigracji politycznej jest zjawiskiem stałym"2.

Jako przykład przewidywanego zjawiska przechodzenia od emigracji politycznej ku narodowi diaspory Mieroszewski wskazał początek kariery młodego naukowca, którego ukrył pod fikcyjnym nazwiskiem Jan Kowalski. Wykładowca historii Europy Wschodniej na uniwersytecie Indiana, obywatel amerykański; gimnazjum rozpoczął w Polsce, maturę zdał we Francji, tytuł doktorski uzyskał na uniwersytecie londyńskim. Przez dwa lata studiował na Columbia University i nostryfikował swój dyplom - tak przedstawiał Mieroszewski swego bohatera. „Pisał mi, że włożył wiele pracy, by przyswoić sobie prawidłowy akcent amerykański. Dziś p. Jan Kowalski nie różni się niczym od młodych naukowców amerykańskich, a jego przełożeni wróżą mu wybitną karierę uniwersytecką. P. Jan Kowalski ma większe możliwości oddziaływa-

1 Piotr Wandycz wskazuje na znaczenie cezury roku 1950 także w dziejach polskiej historiografii na uchodźstwie - zob. P. Wandycz, Historycy i historia na emigracji, [w:] Nauka polska wobec totalitaryzmów w 55 rocznicę wybuchu II wojny światowej, red. B. Orłowski, Warszawa 1994, s. 78.

2 J. Mieroszewski, Polacy i... poganie („Kultura”, nr 9/1954), [w:] tegoż, Finat klasycznej Europy. Wybrał, opracował i wstępem opatrzył R. Habielski, Lublin 1997, s. 143. 
nia na opinię amerykańską niż 100 pisarzy zrzeszonych w Związku Pisarzy Polskich na Obczyźnie. Być może w grupie jego studentów znajduje się przyszły prezydent Stanów Zjednoczonych lub przyszły sekretarz stanu. W każdym razie większość jego uczniów zajmie w przyszłości stanowiska polityczne czy to w służbie zagranicznej, czy w licznych biurach departamentu stanu. P. Kowalski symbolizuje owo niezmiernie ważne stadium przejściowe w ewolucji Polonii. Mimo że urodzony $\mathrm{w}$ Polsce, nie jest już emigrantem politycznym. Nie jest również w dosłownym sensie 'Amerykaninem polskiego pochodzenia' - jeżeli termin ten zacieśnimy do Polaków urodzonych w Stanach Zjednoczonych. P. Kowalski jest naturalizowanym obywatelem amerykańskim, który szczęśliwie wyminął ślepą uliczkę Free Europe i zdołał odnaleźć swoje własne miejsce pod amerykańskim niebem”3.

Analizując ów wybrany przez siebie przykład, Mieroszewski wskazywał w nim zjawisko szersze, które musiało wystąpić w emigracyjnym „drugim pokoleniu” wśród ludzi, którzy wyszli z Kraju w czasie wojny zbyt młodzi jeszcze, by zrosnąć się z instytucjami i mentalnością II Rzeczypospolitej i zdążyć odegrać poważną rolę w czasie samej wojny. Ich kariera życiowa wiązała się w całości z okresem powojennym. Od tego - w jakim stopniu ta kariera, to życie, będą związane z polskością, z jakim jej rozumieniem - zależy skuteczność wolnościowej, wyzwoleńczej misji emigracji w nowych warunkach. Za najsłuszniejszą drogę do spełnienia owej misji Mieroszewski uznawał wyprowadzenie Polaków, właśnie tych z „drugiego pokolenia”, z izolacji, z getta politycznego, kulturalnego i intelektualnego. „Musimy wejść w społeczeństwa zachodnie, jeżeli chcemy wywierać formatywny wpływ polityczny i kulturalny"4.

Publicysta „Kultury” rozumiał, iż „p. Kowalski nie będzie mógł być takim Polakiem jak każdy z nas. Jego polskość będzie czymś innym i różnym niż totalna, bezkompromisowa polskość Cata-Mackiewicza. Ale z tej innej, 'węższej' polskości p. Kowalskiego nie możemy zrezygnować, gdyż możliwości oddziaływania politycznego owej 'węższej' polskości panów Kowalskich są niepomiernie większe niż możliwości politycznego oddziaływania Catów-Mackiewiczów. I z tego względu polskość Kowalskich jest dla nas politycznym zagadnieniem o olbrzymim znaczeniu”.

Dziś, zastanawiając się nad rolą społeczną, polityczną, kulturotwórczą i opiniotwórczą emigracji, powinniśmy uwzględnić chyba i te aspekty jej historii, które mieszczą się w losach ludzi owego „drugiego” (i „trzeciego” później) pokolenia, oddziałującego nie tylko na samo środowisko wychodźcze, i nie na Kraj tylko, ale także na elity społeczeństw zachodnich, w które wchodzili. Nie tylko bezpośrednio w dziedzinie polityki - jak choćby, przykład najbardziej znany, Zbigniew Brzeziński - i nie tylko na polu literatury czy sztuki, ale również w nauce, w szczególności w naukach społecznych, jak również w publicystyce i mediach. Jak, przekraczając granicę wąsko rozumianej, „starej” rzec można emigracji, realizowali tę misję, którą

\footnotetext{
3 Tamże.

4 Tamże, s. 146.

5 Tamże, s. 144-145.
} 
wskazywał w swym wizjonerskim artykule Mieroszewski? Na jak wiele sposobów było to możliwe?

$\mathrm{Tu}$, wraz z zachętą do podjęcia szerokich studiów porównawczych nad owym zagadnieniem przedstawimy tylko dwa przykłady dróg życiowych, w których owe sposoby mogły się ujawniać.

Pan Kowalski, jak już wspomnieliśmy, był postacią rzeczywistą. Jego pierwowzorem dla Mieroszewskiego był jego kuzyn, Piotr Stefan Wandycz ${ }^{6}$. Urodził się 20 IX 1923 roku w Krakowie. Syn Damiana Stanisława, menedżera polskiego przemysłu naftowego, oraz Stefanii z Dunikowskich, autorki książek dla dzieci (jej siostra, Maria, była matką Juliusza Mieroszewskiego $)^{7}$. Małą maturę zdał tuż przed wojną we Lwowie. 17 IX 1939 przeszedł wraz z rodziną granicę rumuńską, by wiosną 1940 dotrzeć do Francji. Po zdaniu matury w polskim liceum w Villard de Lans w 1941 rozpoczął studia historyczne na Uniwersytecie Grenoble (1941-1942). Jesienią 1942 przedostał się do Anglii, gdzie wstąpił do Wojska Polskiego, służąc najpierw jako kanonier w artylerii 1 Dywizji Pancernej gen. Stanisława Maczka, potem w szkole podoficerskiej, wreszcie po podchorążówce - w Centrum Wyszkolenia Artylerii w Szkocji, gdzie zajmował się szkoleniem żołnierzy. Po zakończeniu wojny pozostał na emigracji.

Włączył się w jej życie polityczne i zainspirowany przez starszego kolegę ze Lwowa, Jerzego Lerskiego „Jura”, wstąpił do Polskiego Ruchu Wolnościowego „Niepodległość i Demokracja", kierowanego przez Rowmunda Piłsudskiego ${ }^{8}$. Działał w Związku Polskich Federalistów, któremu „NiD” patronował. Kontynuował jednocześnie swe studia historyczne: w latach 1945-1948 w Cambridge, 1948-1951 w London School of Economics and Political Science. Tamże uzyskał doktorat na podstawie rozprawy przedstawiającej wkład XIX-wiecznej francuskiej i brytyjskiej myśli liberalnej do

$6 \mathrm{~W}$ opracowaniu przedstawionych danych biograficznych profesora Wandycza wykorzystuję publikowany już wcześniej przeze mnie jego biogram ([w:] Leksykon kultury polskiej poza krajem od roku 1939, t. 1, red. K. Dybciak i Z. Kudelski, Lublin 2000, s. 459-460), biogram pióra Marka Szczerbińskiego - Od polityki do historii. Zarys biografii Piotra Stefana Wandycza, [w:] Studia z dziejów Polski i Europy w XIX i XX wieku. Ksiega dedykowana Profesorowi Piotrowi Stefanowi Wandyczowi, red. J. Faryś, ks. R. Nir, M. Szczerbiński, Gorzów Wlkp. 2004, s. 7-12, jak również wiadomości zaczerpnięte z rozmów: P. S. Wandycz, O federalizmie i emigracji. Reminiscencje o rzeczach istotnych i błahych. Rozmowy prowadził Sławomir Łukasiewicz, Lublin 2003; Czy Polska jest małym narodem? - z profesorem Piotrem Wandyczem rozmawia Andrzej Nowak, „Arka”, nr 34: 4/1991, s. 91-98; wreszcie moją korespondencję e-mailową z profesorem Wandyczem - z października-grudnia 2012 r. (uzupełnioną w marcu 2013).

7 W e-mailu przesłanym mi 6 marca 2013 prof. Wandycz uzupełnił te informacje: „[...] odnośnie moich rodziców, którzy (zwłaszcza moja matka) wywarli na mnie ogromny wpływ: Ojciec legionista 1 Brygady, był po wojnie prezesem koła 6 batalionu i radnym miasta Lwowa. W 30-ych latach został mianowany dyrektorem 'Polskiego Eksportu Naftowego', nowo powstałej instytucji koordynującej działalność firm naftowych prywatnych i państwowych (ciekawy eksperyment, mało znany nawet ekspertom jak Landau). Co do mojej matki, to pochodziła z bardzo starej rodziny ziemiańskiej co wspominam nie przez snobizm - matka była lewicowych poglądów - ale ponieważ była przywiązana do tradycji co wpłynęło na mnie".

8 Por. A. Trudzik, Polski Ruch Wolnościowy „Niepodległość i Demokracja” i jego organ prasowy „Trybuna”. Dzieje Ruchu, periodyku i innych czasopism wydawanych przez PRW „NiD”, Warszawa 2009. 
teorii stosunków międzynarodowych. Równolegle (1950-1951) brał udział w trzysemestralnych warsztatach nowo otwartego Kolegium Europejskiego w Brugii.

W grudniu 1951 wraz z bratem i siostrą przeniósł się ze względów rodzinnych do Stanów Zjednoczonych (ojciec przebywał w Ameryce od 1944 roku, wymagał w tym momencie opieki). Od połowy 1952 roku mógł wrócić do badań naukowych, uzyskując wsparcie ze strony profesora Feliksa Grossa, który uczynił go swoim asystentem w Mid-European Studies Center. W ramach tej pracy przygotował swą pierwszą książkę: Czechoslovak Polish Confederation and the Great Powers 1940-1943 (Bloomington, Indiana University Slavic and East European Series, Vol. 3, 1956). W 1954 roku kandydaturę Wandycza na wykładowcę w Indiana University w Bloomington zaproponował Norman J. Pounds, znany geograf brytyjski, który był wcześniej jego tutorem w Cambridge. Po przeniesieniu do USA Pounds zaczął organizować na Uniwersytecie Indiana ośrodek studiów wschodnio-europejskich i chciał tam mieć „,swojego człowieka”. Wandycz wykładał nowożytną historię Europy Środkowo-Wschodniej na tymże uniwersytecie do 1966 roku. W latach 1963-1965 współpracował z głównym ośrodkiem sowietologiczno-rosjoznawczym w Ameryce, Russian Research Center, na Uniwersytecie Harvarda. W 1966 roku otrzymał propozycję zatrudnienia na jednej z najbardziej prestiżowych uczelni amerykańskich - Yale University - gdzie od 1968 zyskał etat „pełnego” profesora. Zajmował na tej uczelni liczne stanowiska administracyjne, m.in. Director of Graduate Studies (1967-1972, 1978-1979), Chairman of the Council on Russian and East European Studies and Director of Language and Area Center (1974-1976, 1981-1983), a przede wszystkim publikował kolejne fundamentalne dzieła naukowe z zakresu dyplomacji europejskiej pierwszej połowy XX wieku oraz historii Europy Środkowej i Wschodniej XIX-XX wieku. Wymienimy tylko najważniejsze tytuły: France and her Eastern Allies 1919-1925: French-Czechoslovak-Polish Relations from the Paris Peace Conference to Locarno (Minneapolis 1962); Soviet-Polish Relations 1917-1921 (Cambridge, Mass. 1969); The Lands of Partitioned Poland 1795-1918 (Seattle 1974); The United States and Poland (Cambridge, Mass. 1980); The Twilight of French Eastern Alliances 1926-1936: French-Czechoslovak-Polish Relations from Locarno to the Remilitarization of the Rhineland (Princeton 1988); The Price of Freedom A History of East Central Europe from the Middle Ages to the Present (London, New York 1992, tłumaczona na polski, litewski, czeski, węgierski, bułgarski, włoski, chorwacki).

Choć w 1960 roku przyjął obywatelstwo amerykańskie, to jednak nadal uczestniczył w życiu, przede wszystkim naukowym, emigracji, m.in. jako członek Polskiego Instytutu Naukowego oraz Instytutu Józefa Piłsudskiego w Nowym Jorku, Instytutu Historycznego w Rzymie, Towarzystwa Historyczno-Literackiego w Paryżu, Zrzeszenia Polskich Profesorów i Docentów na Obczyźnie. Współpracował także nadal ze Związkiem Polskich Federalistów (gdzie działał również m.in. Oskar Halecki). Pisywał wiernie (od 1949 do 1991 roku) do organu NiD-u - „Trybuny”. W 1951 roku, za pośrednictwem swego kuzyna, Juliusza Mieroszewskiego, podjął pierwszą nieudaną próbę publikacji w paryskiej „Kulturze”. Jerzy Giedroyc odrzucił 
propozycję artykułu-reportażu z wycieczki do Niemiec 28-letniego wtedy Wandycza jako „młodzieńczą próbkę”. Regularna współpraca autorska nawiązała się dopiero od 1957 roku - od artykułu w „Kulturze”. Profesor Wandycz stał się ostatecznie jednym z filarów ukazujących się od 1962 do 2010 roku „Zeszytów Historycznych”10.

Jednocześnie od momentu uzyskania obywatelstwa amerykańskiego zdecydował się na regularne wizyty w kraju. Swoje stanowisko określił w następujący sposób: „Moje nastawienie wówczas było takie, że ja się uważam za emigranta politycznego. Jeżeli istnieje taki układ, że PRL mnie wpuszcza w tym okresie, to będę z tego korzystał, ale ograniczę się jedynie do swojej pracy zawodowej, naukowej. [...] Było takie nastawienie, że jeśli się jest na Zachodzie - emigracja czy nie emigracja - jeżeli są możliwości rozmów i trzymania ręki na pulsie wydarzeń w Polsce, to należy to wykorzystywać w pełni. Tak argumentowali i Bromke [Adam] i Zbyszek Pełczyński z Anglii" ${ }^{11}$. Odwiedzał regularnie biblioteki i archiwa w Krakowie i Warszawie, zatrzymując się na dłuższe (roczne) pobyty na Uniwersytecie Jagiellońskim (w 1972-1973 i 1977-1978), gdzie więzy szczególnej bliskości zadzierzgnął z „nadzwyczajnym profesorem" - Henrykiem Wereszyckim i jego kręgiem przyjaciól-historyków ${ }^{12}$. Stał się swego rodzaju „łącznikiem” między historiografią emigracyjną, przede wszystkim nauką zachodnią, a współczesną historiografią polską, tworzoną w warunkach cenzuralnych ograniczeń PRL.

Przede wszystkim jednak w swych wielkich dziełach oraz też w setkach recenzji i not, a także niezwykle ważnych w skali swego oddziaływania hasłach encyklopedycznych (m.in. hasła o Długoszu i księciu Adamie Jerzym Czartoryskim dla Encyclopaedia Americana - 1974 czy obszerne hasło Poland-History dla 15 edycji Enclopaedia Britannica ${ }^{13)}$, a wreszcie jako współautor francuskiej syntezy dziejów

9 Drętwa mowa, „Kultura”, nr 5/1957, s. 64-69.

10 Zob. P. Wandycz, „Zeszyty Historyczne”, [w:] Jerzy Giedroyc. Redaktor, polityk, człowiek, oprac. Krzysztof Pomian, Lublin 2001 s. 276-287; S. Nowinowski, Historia dyplomacji II Rzeczypospolitej na łamach "Zeszytów Historycznych”, [w:] Jerzego Giedroycia rozrachunki z historia i polityką. Studia i szkice w czterdziestą rocznicę "Zeszytów Historycznych", red. S. M. Nowinowski, R. Stobiecki, Łódź 2005, s. 35-49.

11 Cyt. za: P. S. Wandycz, O federalizmie i emigracji..., s. 76. W e-mailu przysłanym mi 6 marca 2013 r. prof. Wandycz uzupełnił te informacje komentarzem: „Istotnie obywatelstwo USA przyjąłem w 1960 r., aby móc pojechać do Polski a mój status jako bezpaństwowca (przez 15 lat) uniemożliwiał taką jazdę. Moje dalsze odwiedziny Kraju zaczęły się regularnie od 1972 roku czyli po 12-letniej przerwie. Spowodował ją fakt, że moje nazwisko znalazło się w procesie Hanny Rudzińskiej, którą poznałem via Giedroyc i która wprowadziła mnie do klubu Krzywego Koła. Po moim wyjeździe Wojtek Ziembiński ostrzegł mnie przez znajomych, żebym się nie pokazywał w Polsce. Ten fakt m.in. różnił mnie od Adama Bromkego i Zbyszka Pełczyńskiego, którzy zwłaszcza ten pierwszy nawiązywali kontakty z establishmentem. Adam potem został doradcą premiera. Ja odmawiałem wywiadu dla Trybuny Ludu, a także nie chciałem występować jako przedstawiciel amerykański. I tak zignorowałem zaproszenie na konferencję urządzaną przez CIA i odmówiłem towarzyszenia prof. Byrnesowi w jego oficjalnej podróży do Polski (B. miał też jakieś związki z CIA)”.

12 Zob. P. Wandycz, Między starymi a nowymi laty..., [w:] Henryk Wereszycki (1898-1990). Historia w życiu historyka, red. Elżbieta Orman, Antoni Cetnarowicz, Kraków 2001, s. 263-272.

13 Vol. 25, 1998, s. 940-956. 
naszego regionu ${ }^{14}$ - podejmował świadomie rolę „tłumacza” sprawy polskiej, a szerzej środkowo-wschodnioeuropejskiej historii dla zachodniego odbiorcy.

Z uzyskanej swą wytrwałą pracą pozycji profesora Yale University, uznanego autorytetu światowej historiografii XX wieku, mógł tej roli podejmować się z nadzieją na skuteczność, o jakiej historycy starszego, „pierwszego” pokolenia, pozostający w węższym kręgu emigracji - nawet tak wybitni, jak Oskar Halecki czy Marian Kukiel - mogli tylko marzyćc ${ }^{15}$.

Czy obecny (od 1997 roku) profesor emeritus, dwukrotny laureat najwyższej nagrody Amerykańskiego Towarzystwa Historycznego - George Louis Beer Prize (1962 i 1989), członek rad redakcyjnych najbardziej wpływowych światowych periodyków naukowych w dziedzinie historii („International History Review”) i slawistyki („Slavic Review”), członek komitetu doradczego Yale University Press Series, a zarazem wieloletni prezes PIASA (1999-2008), członek PAU i PAN, doktor honoris causa Uniwersytetu Wrocławskiego, Jagiellońskiego, KUL, Sorbony (Paris 1) - czy to rzeczywiście jest spełnienie snu o karierze Jana Kowalskiego, którego opisał Mieroszewski? To jest wzór przedstawiciela Polonii „drugiego pokolenia” - tej, która wyprowadza Polaka z izolacji? Jak ów wzór wygląda w porównaniu z innymi, wypełnionymi w losach innymi emigrantami, uczonymi czy politykami?

Warto posłuchać, co sam Piotr Wandycz ma na ten temat do powiedzenia. Zapytany o swoje podobieństwo do Jana Kowalskiego z tekstu Mieroszewskiego, stwierdził, że o roztopienie się w amerykańskim środowisku naukowym na pewno nie zabiegał: „[...] nigdy nie lubiłem amerykańskiego akcentu, nie starałem się być bardziej amerykański niż Amerykanie, i nie próbowałem wchodzić w życie amerykańskie w ten sposób. To by bardziej pasowało do Brzezińskiego niż do mnie..."16. Wandycz - inaczej niż Brzeziński - nie chciał stać się Amerykaninem, nie chciał przyjmować nawet żadnych ról, czy funkcji, które mogłyby go wobec kraju postawić w roli amerykańskiego urzędnika. Chciał pozostać - jak sam pisze - „raczej naukowcem $\mathrm{z}$ zainteresowaniami politycznymi niż człowiekiem $\mathrm{z}$ temperamentem politycznym”; chciał pozostać emigrantem, ale - „nie tylko Polakiem, ale także Europejczykiem, który mieszka w Ameryce"17.

W tej roli, którą wybrał i realizował z powodzeniem, liczył, że jego książki skorygują w środowiskach akademickich bodaj niektóre przynajmniej obiegowe opinie negatywne o Polsce. Jako przykład takiego oddziaływania, bardziej skutecznego aniżeli głośne protesty emigrantów w ich własnym środowisku przeciwko świadomym paszkwilom przeciwpolskim, albo też uproszczonym co najmniej sądom powielanym przez akademickie publikacje zachodnich autorów, Wandycz wskazywał głośną w połowie lat 50. książkę Samuela Sharpa White Eagle on a Red

14 Histoire de $l$ \&Europe de Centre-Est, Paris (Nouvelle Clio, Presses Universitaires de France, 2004), fragmenty autorstwa P. S. Wandycza: s. 485-605, 767-826, 845-888.

15 Najlepszym wprowadzeniem do tego zagadnienia jest monografia Rafała Stobieckiego, Klio na wygnaniu. Z dziejów polskiej historiografii na uchodźstwie w Wielkiej Brytanii po 1945 r., Poznań 2005.

16 P. S. Wandycz, O federalizmie i emigracji..., s. 61.

17 Tamże, s. 67-68. 
Field (wydana przez Harvard University Press w 1953). Edycji książki Sharpa nie udało się zastopować, jednak polskie protesty (komentował je także przebywający wtedy na uchodźstwie w Ameryce Melchior Wańkowicz) spowodowały choć tyle, że nie weszła ona do prestiżowej serii prezentującej stosunki Stanów Zjednoczonych z poszczególnymi krajami. Po latach Wandycz został poproszony o wypełnienie wynikającej stąd luki w owej serii i swą książką United States and Poland dał zachodnim czytelnikom kompendium historii Polski połączone z wątkiem relacji amerykańsko-polskich. Połączenie zdobytego już prestiżu profesora Yale University ze zdobytą na seminariach $\mathrm{z}$ amerykańskimi studentami umiejętnością nawiązywania do ich sposobu myślenia o „egzotycznych” sprawach Europy Środkowo-Wschodniej pozwalało kuzynowi Mieroszewskiego mieć nadzieję, że ta forma oddziaływania na umysły amerykańskich, a szerzej zachodnich elit, przynajmniej jakiejś ich części, będzie dobrym spełnieniem misji emigranta „drugiego pokolenia"18.

Widział jednak, na przykładzie Oskara Haleckiego, wielkiego historyka starszego pokolenia, który przez ponad 30 lat (od 1940 roku) żył i pracował na terenie Stanów Zjednoczonych, że uczony-emigrant „pierwszego pokolenia”, pozwalający na skojarzenie swego dzieła ze stereotypem Polaka, z katolicyzmem na dodatek - takiej roli nie mógł wypełnić: ze względu na siłę uprzedzeń zachodnich, amerykańskich w tym wypadku. „Halecki właściwie nigdy nie miał takiej pozycji w amerykańskim życiu akademickim, na jaką zasługiwał. Był trochę takim człowiekiem z zewnątrz, a poza tym bardzo silna była wtedy - to zostało przełamane za Kennedy’ego - niechęć do katolików. Halecki zaś był zdeklarowanym katolikiem, należał do Związku Historyków Katolickich i był nawet jego prezesem"19.

Polish Scientist - Soldier of Liberty - tak zatytułowany był wykład, jaki Oskar Halecki wygłosił na konferencji z okazji 200-lecia Uniwersytetu Columbia w Nowym Jorku (sam był zatrudniony na znacznie mniej prestiżowym uniwersytecie Fordham). W pewnym stopniu tytułem tego wykładu streścić by można sens owej misji, którą i Halecki, i Wandycz, i dziesiątki innych Polaków-uczonych, historyków, socjologów, politologów, slawistów próbowało podejmować poza emigracyjnym środowiskiem, wobec społeczeństw swoich krajów osiedlenia, wobec ich akademickich elit przynajmniej. Piotr Wandycz misję tę wypełniał dyskretnie, nie zrywając kontaktu z emigracją, z jej instytucjami i działaniami, ale występując przede wszystkim jako naukowiec - nie jako „bojownik sprawy polskiej”.

Tym trudniej owym ostatnim określeniem obdarzyć drugiego z bohaterów tego szkicu. I tym bardziej interesujące może być prześledzenie jego ścieżki życia i pełnej pasji aktywności z punktu widzenia tej perspektywy, jaką w 1954 roku nakreślił

18 Zob. tamże, s. 79; por. P. Wandycz, Wstęp. Polacy i Ameryka, [w:] M. Wańkowicz, Kundlizm, Klub Trzeciego Miejsca, Polacy i Ameryka, Tworzywo, Warszawa 2011, s. 152-153; Czy Polska jest matym narodem?..., s. 91-92.

19 P. S. Wandycz, O federalizmie i emigracji..., s. 51; por. P. Wandycz, O dwóch historykach, „Zeszyty Historyczne”, 32 (1975), s. 61-65; tenże, Garść wspomnień, „Przegląd Polski” (Nowy Jork), 4 II 2005. 
przed wychodźcami młodszego pokolenia Mieroszewski. Ów drugi przykład, który chcemy tutaj przedstawić, daje - mocniej związany z Londynem - Leopold Łabędźz ${ }^{20}$.

Urodził się 22 stycznia 1920 r. w Symbirsku, w zasymilowanej w polskiej kulturze rodzinie żydowskiej. Po szczęśliwej ewakuacji z ogarniętej panowaniem bolszewickim Rosji rodzina Łabędziów dotarła do Warszawy. Leopold uczęszczał do słynnego prywatnego gimnazjum Michała Kreczmara w Warszawie (mniej więcej połowę uczniów stanowili żydzi, a połowę katolicy). Idąc w ślady ojca, rozpoczął studia medyczne, najpierw na Uniwersytecie Warszawskim, a następnie (w 1938) na Sorbonie. Walczył w kampanii wrześniowej, która dla niego zakończyła się we Lwowie, dokąd dotarła sowiecka inwazja i okupacja. Jego ojciec został zmuszony do pracy w klinice NKWD. Pozwoliło to na odroczenie aresztowania i deportowania Leopolda Łabędzia do Azji Środkowej - ale tylko o kilka miesięcy. Ostatecznie podzielił los kilkuset tysięcy innych mieszkańców, zagarniętych po 17 września przez ZSRR ziem II Rzeczypospolitej, zesłanych do obozów pracy w Kazachstanie i na Syberii. Wuj Leopolda został zastrzelony w Katyniu. Sam Leopold zdołał wydostać się ze Związku Sowieckiego z armią generała Władysława Andersa. Jako kapral artylerii polowej przeszedł z nią szlak bojowy, od Bliskiego Wschodu, poprzez Włochy. Po zakończeniu wojny powrócił do studiów, ale już nie medycznych, lecz socjologii i ekonomii w London School of Economics (pod kierunkiem Rajmunda Poppera); uczęszczał tam także na seminarium Leonarda Schapiro poświęcone polityce sowieckiej. Tam także - to jest w Londynie - w 1955 roku został przez Waltera Laquera poproszony do pomocy przy wydawaniu czasopisma „Soviet Survey”. Od 1961 został jego współwydawcą, a od 1964 wyłącznym redaktorem (już pod nazwą „Survey”). Z miesięcznego 4-stronicowego biuletynu, wydawanego od śmierci Stalina, Łabędź rozwinął pierwszy poważny magazyn poświęcony studiom sowietologicznym w Europie Zachodniej, czytany regularnie przez najbardziej wpływowych polityków zachodnich aż do końca Zimnej Wojny. Kwartalnik „Survey” $\mathrm{z}$ biura redakcyjnego na Lower Oxford Street w Londynie trafiał na biurka w Białym Domu, Departamencie Stanu, Whitehall, a nawet na Kremlu.

Łabędź wykładał gościnnie na tematy sowieckie w najbardziej prestiżowych uniwersytetach amerykańskich i europejskich. Jako członek rady redakcyjnej i stały autor miesięcznika „Encounter”, jednego z najznakomitszych periodyków intelektualnych w świecie anglojęzycznym, mógł Łabędź także oddziaływać na szerszą publiczność swymi poglądami na temat systemu sowieckiego i komunizmu ${ }^{21}$. Wśród

20 Podstawowe informacje na temat życia i twórczości Leopolda Łabędzia podaję za opracowanym przez siebie wcześniej biogramem w: Leksykon kultury polskiej..., s. 232-233; por. także A. Nowak, A „Polish Connection” in American Sovietology, Or the Old Homeland Enmities in the New Host Country Humanities, „Ab Imperio” (Kazań), 4/2007, s. 237-259; toż w: A. Nowak, History and Geopolitics: A Contest for Eastern Europe, Warszawa 2008, s. 329-352. Wykorzystuję także wspomnienia Edwarda Shilsa: Portraits. A Gallery of Intellectuals, Chicago 1997, s. 155-177; jak również opublikowane po śmierci Leopolda Łabędzia nekrologi pióra Adama Zamoyskiego w „The Independent”, 27 III 1993 oraz Radosława Sikorskiego w „National Review”, 26 IV 1993.

21 Najlepszym wprowadzeniem do tej roli Łabędzia jest książka Petera Colemana, The Last Intellectuals: Essays on Writers \& Politics, Melbourne 2010. 
bezpośrednich odbiorców jego idei i przyjaciół znaleźli się m.in. sir Isaiah Berlin, Edward Shils, senator Scoop Jackson, Richard Perle. Swoje koncepcje i demaskacje sowieckich kłamstw Łabędź wyłożył w licznych publikacjach przez siebie przygotowanych i zredagowanych, takich jak Revisionism. An Essay in Marxist Ideas (1963), Revisionism. Essays on the History of Marxist Ideas (1962), Polycentrism (współredagowany z Walterem Laqueurem, 1962), Literature and Revolution in Soviet Russia 1917-1962 (1963), International Communism after Khruschev (1965), Khruschev and the Arts. The Politics of Soviet Culture, 1962-1964 (1965), On Trial: the Case of Siniavsky and Daniel (1967), Solzhenitsyn. A Documentary Record (1974), Poland Under Jaruzelski. A Comprehensive Sourcebook on Poland During and After Martial Law (1983). Ostatni zbiór esejów - Use and Abuse of Sovietology $(1988)^{22}$ - uznawany jest za jego intelektualny testament. Zmarł w Londynie 22 marca 1993 roku.

Choć żył w centrum spraw światowych, będąc stałym punktem odniesienia w dyskusjach o sprawach sowieckich i sporach z komunizmem, to jednocześnie ze swoją towarzyską swadą, humorem, intelektualną werwą był także obecny w życiu Polaków w Londynie - tych ze „starej” emigracji, swoich towarzyszy broni z II Korpusu, i tych także, którzy - zwłaszcza po stanie wojennym - przyjeżdżali tutaj z kraju ${ }^{23}$.

By dać przykład jego zaangażowania w sprawy polskie, wybrać można choćby kilka lat jego współpracy z paryską „Kulturą”. Rozpoczęła się ona w końcu lat 50., a zakończyła burzliwie w 1963 roku w związku ze sporem między redaktorami o to, kto szybciej opublikuje atrakcyjny materiał z procesu pierwszych sowieckich dysydentów literackich - Andrieja Siniawskiego i Jurija Daniela ${ }^{24}$. Oto w 1959 roku Łabędź, korzystając ze swoich światowych koneksji, dostrzega możliwość zatrudnienia Polaka na katedrze slawistyki w Melbourne - od razu pyta Giedroycia, czy byłby taką ofertą zainteresowany Czesław Miłosz (skądinąd z entuzjazmem piszący wówczas o „Survey” i pomieszczonych tam studiach o marksistowskim rewizjonizmie)? ${ }^{25} \mathrm{~W} 1962$ zamawia z kolei u Miłosza studium o Stanisławie Brzozowskim - chcąc zapoznać współczesną publiczność światową z myślą wielkiego polskiego krytyka ${ }^{26}$. Jednocześnie Łabędź monituje Jerzego Stempowskiego do wyjazdu na organizowane przez siebie w Oksfordzie seminarium o literaturze sowieckiej, na które zaprasza także Aleksandra Wata i Gustawa Herlinga-Grudzińskiego - jakby chciał podkreślić, że w „wolnym świecie" Polacy są w tej fascynującej Zachód dziedzinie najlepszymi specjalistami ${ }^{27}$. Inny

22 Polskiemu czytelnikowi myśl redaktora „Survey” przybliża wybór: L. Łabędź, Bez złudzeń. Wybór pism 1962-1988, London 1989.

23 Zob.: „Nazywać rzeczy po imieniu” - z Leopoldem Łabędziem, historykiem, dziennikarzem, sowietologiem rozmawia Paweł Chojnacki, „Arka” 36 (6/1991), s. 90-97; „Robić politykę w brzuchu wieloryba" - autoryzowany wywiad z Leopoldem Łabędziem (przeprowadził Józef Darski [Jerzy Tragalski]), „Contra”, nr 3/1990.

24 J. Giedroyc, Autobiografia na cztery ręce, oprac. K. Pomian, Warszawa 1994, s. 177.

25 Jerzy Giedroyc - Czesław Miłosz, Listy 1952-1963, oprac. M. Kornat, Warszawa 2008, s. 328 (list Giedroycia do Miłosza z 15 I 1959) oraz s. 413 (list Miłosza do Giedroycia z 19 VII 1960).

26 Tamże, s. 600 (list Giedroycia do Miłosza z 31 III 1962).

27 Zob. Jerzy Giedroyc - Jerzy Stempowski, Listy 1946-1969, cz. II, oprac. A. S. Kowalczyk, Warszawa 1998, s. 188 (list Giedroycia do Stempowskiego z 8 III 1962). 
współpracownik „Kultury”, Konstanty Jeleński, namawia wtedy usilnie Łabędzia, by ten - korzystając ze swych bliskich kontaktów z sir Isaiahem Berlinem - „lansował” Wata w świecie anglosaskim ${ }^{28}$.

Z jednej strony zatem zabiegi o to, by polski głos był słyszalny w debacie globalnej o wolności i jej zagrożeniu przez sowiecki system, z drugiej - pełne energii wdzieranie się w samo centrum refleksji i decyzji Zachodu, Stanów Zjednoczonych, by w tej debacie zaważyć skutecznie. Możemy zilustrować tę drugą stronę działalności Łabędzia nie tylko wpływem politycznym kolejnych numerów jego „Survey”, ale takim oto anegdotycznym obrazkiem, zapisanym przez innego polskiego Żyda, współwychodźcę, który odnalazł swe miejsce w świecie akademickim Zachodu - profesora Adama Ulama z Harvard University. Ulam, lwowianin z urodzenia, wieloletni kierownik harwardzkiego Russian Research Center, najważniejszego amerykańskiego ośrodka sowietologicznego, wspomina, jak w październiku 1962 roku, w czasie kryzysu kubańskiego, Leopold Łabędź przyjechał do Harvardu, by krytykować amerykańską politykę, która pozwoliła Związkowi Sowieckiemu na przekształcenie Kuby w wielką moskiewską bazę rakietową i szantażowanie Waszyngtonu. Przybył wprost do gabinetu Ulama w Russian Research Center, by wyładować swą wściekłość. „Leo, razem z Rysiem Pipesem, profesorem historii, a także ze Zbigniewem Brzezińskim, wtedy wciąż jeszcze asystentem na moim wydziale, wysłali depeszę do jednego z decydentów polityki zagranicznej w Waszyngtonie, wzywając do jak najtwardszego stanowiska w sprawie Kuby. Byłoby interesujące dowiedzieć się, który z członków rządu miał w tych gorączkowych dniach czas, by zauważyć i rozważyć tę depeszę od trzech urodzonych w Polsce naukowców?"29

Nie znamy odpowiedzi na to pytanie. Wiemy jednak, że Leopold Łabędź, tak jak Piotr Wandycz, tak jak wspomniany również w owym przywołanym przed chwilą obrazku Zbigniew Brzeziński, jak choćby jeszcze Janusz K. Zawodny, Teresa Rakowska-Harmstone, Zbigniew Pełczyński - to znakomite przykłady takiej właśnie kariery emigracyjnego „drugiego pokolenia”, do jakiej namawiał, jaką wieszczył w 1954 roku Juliusz Mieroszewski. Kariery udanej. Udanej także dla tej sprawy, która była najważniejszą może misją emigracji.

Istotną treść tej polskości, która powinna być w nowych, zrozumiałych dla zachodniego odbiorcy formach zachowana w ludziach „drugiego pokolenia”, stanowić miało według projekcji Mieroszewskiego popieranie polityki wolnościowej i przyczynianie się do rozwoju kultury polskiej na obczyźnie. Nade wszystko jednak właśnie wpływ na społeczeństwa zachodnie w duchu „wierności moralnej koncepcji polskości”, jak to, z lekkim zażenowaniem „frazesowiczowskim” tonem tego określenia, nazwał sam „Londyńczyk”. „Polskość na tle tego, co określamy 'kryzysem współczesnej cywilizacji', urasta do rangi koncepcji moralnej, którą można wyzna-

28 Zob. Jerzy Giedroyc - Konstanty A. Jeleński, Listy 1950-1987, oprac. W. Karpiński, Warszawa 1995, s. 342 (list Jeleńskiego do Giedroycia z 26 VI 1962).

29 A. Ulam, Understanding the Cold War: A Historian's Personal Reflections, Charlottesville 2000, s. $110-111$. 
wać i głosić w każdym języku. Aspekt moralny polskiego poglądu na istotę współczesnego konfliktu stanowi o fundamentalnej różnicy pomiędzy myślą polityczną Zachodu a polską myślą polityczną. [...] Słuszna sprawa nabiera tylko wówczas cech koncepcji moralnej, jeżeli budzi w ludziach gotowość ofiary. Idea wolności utraciła na Zachodzie aspekt moralny i przestała być tą najwyższą wartością, której imperatyw moralny każe bronić, bez względu na ryzyko i ofiary. Wolność odarta z moralności stała się commodity - jedną z wielu w bazarze zachodniej cywilizacji. Jeżeli idei wolności nie potrafimy przywrócić aspektu moralnego, nie zdołamy jej obronić. Bezmoralna wolność nie wydobędzie z młodych Amerykanów czy Anglików, którzy chcą żyć w spokoju i dobrobycie - determinacji, odwagi i gotowości ofiary. Tak jak lęk jest zaproszeniem do agresji - tak bezmoralna wolność jest zaproszeniem do niewoli. Mówiąc o 'misji' Polaków w świecie, miałem na myśli ów moralny aspekt polskości-wolności. To jest więź, która nas łączy, i to jest treść naszego posłania dla ... zachodnich pogan" ${ }^{30}$.

Piotr Stefan Wandycz i Leopold Łabędź - na różne sposoby pokazali, jak skutecznie to przesłanie można było szerzyć wśród zachodnich pogan, nie rezygnując jednocześnie z więzi z polskim środowiskiem na wychodźstwie.

Czy przesłanie to było jednak tylko polskie, emigracyjne? Na pewno nie. Dlatego zachęcając na koniec do kolejnych, bardziej pogłębionych badań nad polskimi wychodźcami „drugiego pokolenia” z sukcesem realizującymi swoje akademickie, polityczne, publicystyczne kariery w świecie zachodnim, pozwalam sobie zasugerować także potrzebę studiów porównawczych tych karier, tych biografii, ich przewodnich motywów ideowych - z karierami, biografiami i przesłaniem czeskich, węgierskich, litewskich, rumuńskich, ukraińskich, rosyjskich, łotewskich, estońskich, białoruskich, słowackich emigrantów-naukowców, którzy sięgnęli także w świecie zachodnim po rolę public intellectuals ${ }^{31}$.

To jest już zadanie kolejnego pokolenia.

The "second generation" of Polish emigrants: reflections and questions in the context of the biographies of Peter Wandycz and Leopold Łabędź

Polish emigration after World War II made a major contribution to the Western academic world, especially in the fields of history and reflection on the political systems in Eastern Europe. This relates in particular to representatives of the so-called second generation of emigrants, i.e. those who were just inaugurating their professional careers in 1945, such as the 22-year-old Piotr Wandycz or Leopold Łabędź, three years his senior. The article is a comparative analysis of the biographies and achievements of these two personages. After a period of political activity within the Polish Freedom Movement "Independence and Democracy" and the Union of Polish

30 J. Mieroszewski, Polacy i... poganie, s. 146-147.

$31 \mathrm{Na}$ tę potrzebę zwrócił ostatnio uwagę także Sławomir Łukasiewicz w dwóch interesujących studiach: Zimnowojenna emigracja polityczna jako przedmiot badań, „Pamięć i Sprawiedliwość”, nr 1 (15), 2010, s. 57-72 oraz Polska emigracja polityczna w XX wieku i pamięć historyczna, „Przegląd Zachodni" 2007, nr 1, s. 63-76. 
Federalists, Peter Wandycz, non-commissioned officer in the $1^{\text {st }}$ Armoured Division in Scotland under the command of General Maczek, eventually pursued a career in academics as a historian. Following his studies at Cambridge University and the London School of Economics (where he earned his doctorate), he emigrated to the U.S. where he first taught at Indiana University in Bloomington, then to join the Chair of History at Yale University. His scientific monographs published in English earned him the recognition as one of the greatest experts on the $20^{\text {th }}$-century European diplomacy, as well as the political history of Eastern Europe. At the same time, he pursued cooperation with émigré periodicals, Jerzy Giedroyc's Kultura and Zeszyty Historyczne in particular. Based on Wandycz's autobiographical material and private correspondence with the author of this article, the latter recreates the motivations for the choice of such a career path and its connection with the concept of the so-called "second generation" of emigrants, formulated in 1954 by Juliusz Mieroszewski, prominent émigré journalist and Wandycz’s cousin. A similar procedure is carried out in relation to the figure of Leopold Łabędź, born three years earlier (in 1920) to a family of assimilated Polish Jews, who served as a non-commissioned artillery officer in the II Corps in Italy under the command of General Anders, then to become one of the most renowned sovietologists, as well as the co-founder (along with Walter Laqueur) and editor of the influential quarterly "Survey". What impact have they achieved on the political consciousness of the Western elites in their respective fields? To what degree were their actions and achievements motivated by a desire to obtain sufficient influence in order to fulfil the specific mission of Polish emigration after WWII: warning the world about Soviet imperialism? These are some of the research questions that this article seeks to answer.

Translated by Jakub Perliński

\section{Эмиграция «второй волны»: размышления и вопросы на полях биографии Петра Вандыча и Леопольда Лабендзя}

Польская эмиграция после Второй мировой войны внесла значительный вклад в западные академические круги, а особенно в историю и размышления над политической системой в Восточной Европе. В частности, это касается представителей т. н. второй волны эмиграции, то есть людей, которые в 1945 году только начинали свою профессиональную карьеру, таких как н. пр. 22-летний тогда Петр Вандыч или на три года старше Леопольд Лабендзь. Статья является сравнительным анализом биографий и достижений этих двух личностей. Петр Вандыч, младший офицер в 1-й бронетанковой дивизии ген. Станислава Мачека в Шотландии, после периода политической активности в Освободительном движении „Независимость и демократия”, а также Союзе польских федералистов, в конечном итоге избрал путь академической карьеры, как историк. Через Кэмбридж и Лондонскую Школу Экономики (здесь он получил докторскую степень), после эмиграции в США его сначала приняли на работу в Индианском университете в Блумингтоне, а в итоге он получил кафедру истории на Йельском университете. Благодаря последующим научным монографиям, опубликованным на английском, он получил признание как один из самых выдающихся исследователей европейской дипломатии XX века, а также политической истории Восточной Европы. Одновременно Вандыч продолжал сотрудничество с эмиграционными журналами, прежде всего с «Культурой» и «Зешиты Хисторычне» Ежи Гедройца.

Пользуясь автобиографическими материалами Вандыча, а также частной перепиской с ним, автор статьи реконструирует мотивировку выбора такой карьерной стези и ее связь с понятием т. н. второй волны эмиграции, которое было сформулировано в 1954 году выдающимся эмиграционным публицистом, двоюродным братом Вандыча, Юлиушем Мерошевским. Похожий прием был применен к силуэту Леопольда Лабендэя, родивше- 
гося на три года раньше (в 1920) в семье ассимилировавшихся польских евреев, младшего офицера артиллерии во 2-м Корпусе ген. Андерса в Италии. После войны он стал одним из самых признанных в мире советологов, сооснователем (вместе с Вальтером Лакером) и редактором очень влиятельного ежеквартального журнала „Сервей”. Каково влияния они добились в своих областях науки на политическое сознание элит Запада? Насколько их действия и достижения мотивировались стремлением получить такое влияние с целью реализовать своеобразную миссию польской эмиграции после Второй мировой войны: предостеречь перед советским империализмом? Это некоторые из исследовательских вопросов данного текста.

Перевод Агнешка Поспишьль

\section{Bibliografia}

\section{Źródła:}

Czy Polska jest małym narodem? - z profesorem Piotrem Wandyczem rozmawia Andrzej Nowak, „Arka”, nr 34: 4/1991.

Giedroyc J., Autobiografia na cztery ręce, oprac. K. Pomian, Warszawa 1994.

Jerzy Giedroyc - Czesław Miłosz, Listy 1952-1963, oprac. M. Kornat, Warszawa 2008.

Jerzy Giedroyc - Konstanty A. Jeleński, Listy 1950-1987, oprac. W. Karpiński, Warszawa 1995.

Jerzy Giedroyc - Jerzy Stempowski, Listy 1946-1969, cz. II, oprac. A. S. Kowalczyk, Warszawa 1998. Łabędź L., Bez złudzeń. Wybór pism 1962-1988, London 1989.

Mieroszewski J., Finał klasycznej Europy. Wybrał, opracował i wstępem opatrzył R. Habielski, Lublin 1997.

Mieroszewski J., Polacy i... poganie, „Kultura”, nr 9/1954.

„Nazywać rzeczy po imieniu” - z Leopoldem Łabędziem, historykiem, dziennikarzem, sowietologiem rozmawia $P$. Chojnacki, „Arka” 36 (6/1991).

"Robić politykę w brzuchu wieloryba" - autoryzowany wywiad z Leopoldem Łabędziem (przeprowadził J. Darski [J. Tragalski]), „Contra”, nr 3/1990.

Shils E., Portraits. A Gallery of Intellectuals, Chicago 1997.

Ulam A., Understanding the Cold War: A Historian's Personal Reflections, Charlottesville 2000.

Wandycz P., Drętwa mowa, „Kultura”, nr 5/1957.

Wandycz P. S., Garść wspomnień, „Przegląd Polski” (Nowy Jork), 4 II 2005.

Wandycz P., Historycy i historia na emigracji, [w:] Nauka polska wobec totalitaryzmów w 55 rocznice wybuchu II wojny światowej, red. B. Orłowski, Warszawa 1994.

Wandycz P., Między starymi a nowymi laty..., [w:] Henryk Wereszycki (1898-1990). Historia $w \dot{z} y c i u$ historyka, red. E. Orman, A. Cetnarowicz, Kraków 2001.

Wandycz P., O dwóch historykach, „Zeszyty Historyczne”, 32 (1975).

Wandycz P. S., O federalizmie i emigracji. Reminiscencje o rzeczach istotnych i błahych. Rozmowy prowadził S. Łukasiewicz, Lublin 2003.

Wandycz P., Wstęp. Polacy i Ameryka, [w:] M. Wańkowicz, Kundlizm, Klub Trzeciego Miejsca, Polacy i Ameryka, Tworzywo, Warszawa 2011.

Wandycz P., „Zeszyty Historyczne”, [w:] Jerzy Giedroyc. Redaktor, polityk, człowiek, oprac. K. Pomian, Lublin 2001.

\section{Opracowania:}

Coleman P., The Last Intellectuals: Essays on Writers \& Politics, Melbourne 2010.

Łukasiewicz S., Polska emigracja polityczna w XX wieku i pamięć historyczna, „Przegląd Zachodni” 2007, nr 1. 
Łukasiewicz S., Zimnowojenna emigracja polityczna jako przedmiot badań, „Pamięć i Sprawiedliwość", nr 1 (15), 2010.

Nowak A., Leopold Łabędź, [w:] Leksykon kultury polskiej poza krajem od roku 1939, t. 1, red. K. Dybciak i Z. Kudelski, Lublin 2000.

Nowak A., Piotr Wandycz, [w:] Leksykon kultury polskiej poza krajem od roku 1939, t. 1, red. K. Dybciak i Z. Kudelski, Lublin 2000.

Nowak A., A „Polish Connection” in American Sovietology, Or the Old Homeland Enmities in the New Host Country Humanities, „Ab Imperio” (Kazań), 4/2007.

Nowinowski S., Historia dyplomacji II Rzeczypospolitej na łamach „Zeszytów Historycznych”, [w:] Jerzego Giedroycia rozrachunki z historia i polityką. Studia i szkice w czterdziesta rocznice „Zeszytów Historycznych”, red. S. M. Nowinowski, R. Stobiecki, Łódź 2005.

Sikorski R., Leopold Łabędź [obituary], „National Review”, 26 IV 1993.

Stobiecki R., Klio na wygnaniu. Z dziejów polskiej historiografii na uchodźstwie w Wielkiej Brytanii po 1945 r., Poznań 2005.

Szczerbiński M., Od polityki do historii. Zarys biografii Piotra Stefana Wandycza, [w:] Studia $z$ dziejów Polski i Europy w XIX i XX wieku. Księga dedykowana Profesorowi Piotrowi Stefanowi Wandyczowi, red. J. Faryś, ks. R. Nir, M. Szczerbiński, Gorzów Wlkp. 2004.

Trudzik A., Polski Ruch Wolnościowy „Niepodległość i Demokracja” i jego organ prasowy „Trybuna”. Dzieje Ruchu, periodyku i innych czasopism wydawanych przez PRW „NiD”, Warszawa 2009. Zamoyski A., Leopold Łabędź [obituary], „The Independent”, 27 III 1993.

Andrzej Nowak - historyk, profesor zwyczajny w Instytucie Historii PAN, kierownik Zakładu Historii Europy Wschodniej na UJ; współzałożyciel i redaktor naczelny dwumiesięcznika "ARCANA" (1994-2012), od 2014 redaktor naczelny "Studiów z Dziejów Rosji i Europy Środkowo-Wschodniej". Zajmuje się głównie historią polityczną i myślą polityczną Europy Wschodniej XIX-XX wieku. Autor ponad 20 książek z historii Polski i Rosji. Opublikował ostatnio: Imperiological Studies. A Polish Perspective (2011), Strachy i Lachy. Przemiany polskiej pamięci (2012), Intelektualna historia III RP (2013), Dzieje Polski - t. I: Skąd nasz ród? (2014), Putin: źródła imperialnej agresji (2014). Gościnnie wykładał historię Europy Wschodniej na uniwersytetach amerykańskich (Rice, Harvard, Columbia), angielskich (Cambridge, London Univ.), kanadyjskich (Univ. of Toronto, McGill, Univ. of Alberta), a także m.in. w Dublinie, Tokio i Brnie. (chlapnowak@neostrada.pl) 